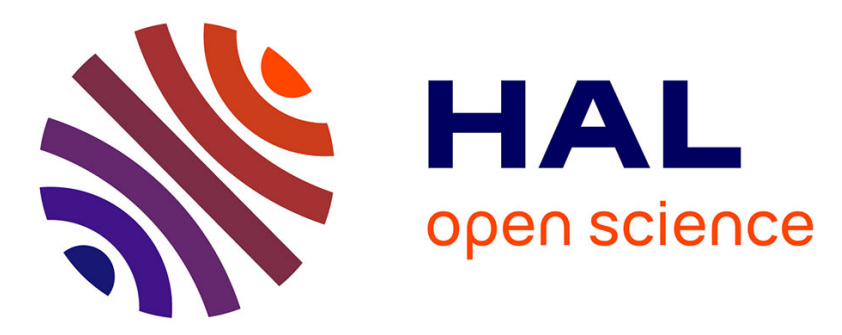

\title{
Effect of attitude toward work, work environment on the employees' work self-efficacy
}

\author{
Abun Dami Damianus, Theogenia Magallanes, T Nicols Marlene, Julian P \\ Fredoline, Michael B Madamba
}

\section{- To cite this version:}

Abun Dami Damianus, Theogenia Magallanes, T Nicols Marlene, Julian P Fredoline, Michael B Madamba. Effect of attitude toward work, work environment on the employees' work self-efficacy. International Journal of Research in Business and Social Science (2147- 4478), 2021, 10, pp.129 - 141. 10.20525/ijrbs.v10i7.1459 . hal-03418398

\section{HAL Id: hal-03418398 \\ https://hal.science/hal-03418398}

Submitted on 1 Dec 2021

HAL is a multi-disciplinary open access archive for the deposit and dissemination of scientific research documents, whether they are published or not. The documents may come from teaching and research institutions in France or abroad, or from public or private research centers.
L'archive ouverte pluridisciplinaire HAL, est destinée au dépôt et à la diffusion de documents scientifiques de niveau recherche, publiés ou non, émanant des établissements d'enseignement et de recherche français ou étrangers, des laboratoires publics ou privés. 


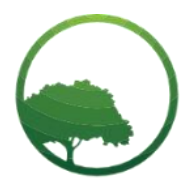

\title{
Research in Business \& Social Science
}

IJRBS VOL 10 NO 7 ISSN: 2147-4478

\section{Effect of attitude toward work, work environment on the employees' work self-efficacy}

\author{
(D) Damianus Abun ${ }^{(a) *(1)}$ Theogenia Magallanes ${ }^{(b)}$ (iD) T. Nicols Marlene ${ }^{(c)}$ (iD) Julian P. Fredoline (d) $^{(0)}$ \\ (iD) Michael B. Madamba ${ }^{(e)}$ \\ (a) Professor, School of Business, Divine Word College of Laoag, Ilocos Norte, Philippines \\ (b) President, Saint Benedict College of Northern Luzon, Ilocos Sur, Philippines \\ (c) Dean, School of Arts, Sciences and Education, Divine Word College of Laoag, Ilocos Norte, Philippines \\ (d) Professor, School of Business, Divine Word College of Laoag, Ilocos Norte, Philippines \\ (e) Professor, School of Arts, Sciences and Education, Divine Word College of Laoag, Ilocos Norte, Philippines

A R T I C L E I N F O
Article history:
Received 12 October 2021
Received in rev. form 29 Oct. 2021
Accepted 03 November 2021
Keywords:
Attitude toward work, cognitive,
affective, humanistic, entrepreneurial,
environment.
JEL Classification:
O15

\begin{abstract}
A B S T R A C T
The study aimed to determine the influence of the attitude of employees toward work and work environment toward work self-efficacy. To deepen the understanding of the study, literature was reviewed and theories were established. The study used the descriptive correlational research design and it used questionnaires to gather the data. The study found that the cognitive attitude of employees toward work is high but the work environment is at a moderate level. Taking the independent variables together, both are correlated to the work self-efficacy of employees. It means that both, attitude toward work and work environment can affect work self-efficacy. Therefore, the hypothesis of the study is accepted.
\end{abstract}

(C) 2021 by the authors. Licensee SSBFNET, Istanbul, Turkey. This article is an open access article distributed under the terms and conditions of the Creative Commons Attribution (CC BY) license (http://creativecommons.org/licenses/by/4.0/).

\section{Introduction}

Organizational success is always the primary aim of any organization. It is the reason why an organization is structured in such a way that the vision and the mission of the organization will be achieved. The management is responsible for the success of the organization. Realizing the vision and mission requires the management to pay attention to different organizational factors that may contribute to the success of the organization. Neglecting to give attention to different factors of the organization may lead to failure. Thus, achieving organizational success is not always simple and easy. It is complex because it involves different factors that need to be given serious attention which need hard work to work on the details.

Many factors may contribute to organizational success such as management, leadership, work environment, organizational relationship, motivation, satisfaction, performance, organizational climate, treatment, and employees' attitude. These factors are interrelated because neglecting one factor may affect the other factors. This is the reason why an organization is called a system. The management needs to have a comprehensive outlook on the organization and give attention to different issues. Based on my experience, some issues that are given little attention by management are the attitude of employees toward their work and the work environment in which employees perform their tasks. The management undermined the effect of these issues on the performance of the organization. Some studies about the effect of attitude on work performance have been conducted such as Khan and Ghauri (2014), Susanty and Miradipta (2013), Abdalkrim and Elhalim (2016), Hettiararchchi and Jayarathna (2014). These studies had the same findings that attitude toward work affects performance and commitment. Related to the effect of work environment on the

* Corresponding author. ORCID ID: 0000-0002-9693-1541

(C) 2021 by the authors. Hosting by SSBFNET. Peer review under responsibility of Center for Strategic Studies in Business and Finance. https://doi.org/10.20525/ijrbs.v10i7.1459 
performance, studies had been done such as Al-Omari and Okasheh (2017), Hafeez, et.al (2019), Duru and Shimawua (2017). These studies have found a positive correlation between work environment and performance. After searching different literature, there have been no studies yet on the effect of attitude toward work, work environment on work self-efficacy of employees.

The issue of self-efficacy is very important in performing a job. The organization or the management needs to have employees who believe in themselves that they can carry out their duties and responsibilities. Therefore, the management must know the extent of the self-efficacy of their employees and continue to develop or improve their self-efficacy through different means. In the school context, self-efficacy becomes a very serious issue because the teachers must convey self-confidence to their students that they are capable and knowledgeable about the subject matter they are teaching. The challenge of management is how to help the employees or teachers to improve their self-efficacy. It must be recognized that enhancing self-efficacy is not also simple as how we talk about it because self-efficacy is contributed by different factors such as knowledge, skills, past mastery experience, vicarious experience, and many other individuals and social factors that contribute to it. In other words, self-efficacy is context-dependency in which the environment may block or facilitate self-efficacy (Conger \& Kanungo, 1988). Thus, the current study aims to see the different dimensions of attitude and work environment and to find out if they affect the work self-efficacy of employees. Changing attitudes and changing the work environment can help improve self-efficacy.

The study is divided into several parts. The first part is the introduction which explains the rationale or the background of the study and the objective of the study. The second part is the review of the literature. It investigates other related literature that discusses the current topic. The purpose is to provide a better understanding of the topic on hand and to propose theories of the study as the basis for investigation. The third part is the research methodology that explains the research design, population, locale, procedures, data gathering instruments, and statistical treatment of data. The fourth part is the data presentation and analysis. This part presents the data that was gathered through questionnaires in table form and followed by interpretation and analysis. The fifth part is the result and discussion which discusses further the implication of the research to the management of the organization and finally its conclusion.

\section{Literature Review}

The purpose of the literature review is to gain more ideas about the subject matter based on the past literature or researches. Besides gaining more ideas, it helps establish the theories of the study to be investigated. Finding more literature on the subject matter would help the researcher to establish a solid understanding of the topic and to establish theories that guide the investigation. Therefore, the literature review will be arranged thematically based on the topic of the study.

\section{The Definition of Attitude and attitude toward work and its Effect on work performance}

Defining attitude is an important step to understanding and defining attitude toward the work. Merriam Webster dictionary defines attitude as "a mental position concerning a fact or state" and a feeling toward a fact or state". The essential element of this definition is a mental and emotional position of a person toward a fact, person, object, or event. A similar definition is offered by the Cambridge dictionary which defines attitude as "a feeling or opinion about something or someone, or a way of behaving that is caused by this". This definition offers three dimensions of attitude which are affective, cognitive, and conative elements. This suggests that feeling and opinions cause certain behaviour and therefore behaviour is not separated from feeling and opinion and forms an integral part of attitude. Feeling and opinion boil down to certain behaviour. This definition offers us the additional element of attitude which is behaviour. Mental and feeling toward a certain object or someone lead to a certain behaviour toward such object or someone. Based on these definitions, attitude is the area of social psychology. It has been discussed by social psychologists since the early $19^{\text {th }}$ century. Thus, the concept of attitude is considered an old concept and it is within the field of social psychology as Allport (1935, p. 798) contended that "the concept of attitude is probably the most distinctive and indispensable in the contemporary American social psychology. No other term appears more frequently in the experimental and theoretical literature". Then Allport (1935, p. 810) defined attitude as "mental and a neural state of readiness, organized through experience, exerting a directive or dynamic influence upon the individual's response to all objects and situations with which it is related". This definition refers to attitude as a set of beliefs, emotions, and behaviour toward a particular person, object, or event as a result of experience. In other words, a person forms certain beliefs, emotions that lead to a certain behaviour toward that particular person, object, or event. The attitude influences or drives the behaviour of the person (Cherry, 2021). According to Titchener (1910), as cited by Ortmeyer (1949), attitude may or may not appear in consciousness or appear as passive or active imagination which is composed of sensations, images, and feelings, and argued that they are behind everything that influences the behaviour. Along with such a concept, Koffka (1935) contended that attitude is a force directed toward the object and the origin of the ego of the individual and according to Dewey (1922), as cited by Ortmeyer (1949) it is acquired and self-active which lead to action. Thus, Thurstone (1929) defines attitude as "man's inclination and feelings, prejudice or bias, preconceived notions, ideas, fear, threats, and convictions about any specific topics". It is seen as the power behind the behaviour of an individual toward a certain object or a person (Baysal \& Tekarslan, 1996, p. 254). Ajzen (1993), Myers (2013), Perloff (2013), Liska (1974) consider attitudes as a cognitive, affective, and conative response toward a certain object, person, or event.

Based on the above definitions, we can define the attitude toward work as a mental and emotional state toward the work which affects the behavioural intention to work. Aries and Rizqi (2013) defined attitude toward work as the feelings of the workers toward different 
aspects of the work environment. It is their feelings, emotions, belief, judgment, appraisals, opinions toward the work and its environment. This definition is important to consider because work cannot be performed apart from the environment. While Önal, (2015) as cited by Akcay, et.al (2016) defined attitude toward work as "tendencies occurring based on individuals' evaluations of their work". In line with the definition of Ajzen (1993), Myers (2013), Perloff (2016), Liska (1974), attitude toward work means a cognitive, affective, and conative response of the worker toward the work. It is what employees believe, and feel about the work which affects their behaviour toward the work. The response or the judgment of the employees toward the work may be positive or negative depending on their experience with the work (Abun, et.al 2021).

As we have understood from the effect of attitude toward behaviour, the same is true with the attitude toward work. It can affect the work performance of employees as found by the study of Abun, et.al (2021). The study found that there is a correlation between the attitude toward work and work performance. Abdalkrim and Elhalim (2016), also had found that attitude toward work affects not only job performance but even job satisfaction. A similar study by Akcay, et.al (2016) also pointed out that the attitude of employees toward their work affects their work. Those findings suggest that the management must be able to change the attitude of employees toward their work to improve their performance level. Improving employees' attitude toward work can lead to job satisfaction, commitment and workaholism, and turnover intention (Borst, et.al, 2019). Therefore, negative attitudes toward the work must be reversed to become positive because it can affect their performance (Menon \& Priyadarshini, 2018). A positive attitude toward work enhances the performance of the employees (Almeida, et.al, 2012).

\section{Work Environment: Humanistic and Entrepreneurial Environment}

In the early days of management, particularly in the 1900s, managers were trapped by Taylor's style of management. Taylor introduced scientific management to improve productivity. Decisions were no longer using the rule of thumb of the management but decisions should be based on data, science. Every time the management introduced something, then they measure the effect if it increases productivity or not. Among other things, Taylor assumed that salary, production techniques, and work environment were important factors to increase workers' productivity, though in reality it was caused by the assembly line in the factory (Walden, 2004). This was the time, the management was busy devising incentives, production techniques, and physical environment set-ups, standardized jobs, to improve efficiency and increase productivity, while management neglects social processes in decision making, the well-being of employees, and job satisfaction of employees (Walden, 2004). From the early researches about the work environment, we can only argue that the work environment is a generic term to include many aspects of organizational management. It includes not only the physical environment of the workplace but includes the social and psychological work environment. Therefore, researchers related to the workplace environment have broadened the coverage of their investigation on the work environment which includes internal and external work environments. Since the environment is an umbrella term that covers many dimensions of the organization, many researchers have come out with different dimensions of the workplace environment. Briner (2000) as cited by Oludeyi (2015) identified several elements that are comprising work environments such as physical settings (office setups, buildings), job characteristics (work complexities), broader organizational features (culture, history), and extra organizational setting (an external environment that affects the workplace). Opperman (2002) as quoted by Yusuf and Metiboba, (2012) and Oludeyi (2015) identified three elements of the work environment namely technical environment (tools, equipment, technological infrastructure, and other physical or technical elements of the workplace), human-environment (human relationships among employees and supervisors), tasks and the national environment which encompasses suppliers, customers, stakeholders, sociocultural factors, national economy, technology, legal system, institutional policies and work policies and philosophies.

Based on the concept of work environment that we have discussed above, then we define work environment as everything inside and outside the organization that affects the work performance. Investigating the work environment as a whole would be complex and thus, researchers need to identify which area of the work environment needs to be given attention. Since it encompasses many elements, thus, the current study focuses on one of the factors identified by Opperman (2002) which is the human environment. The current study focuses on two elements of the human environment which are humanistic and entrepreneurial environment (Abun, et.al, 2021). These two dimensions explain how employees are treated by the organization.

\section{Humanistic Environment}

To understand the concept of a humanistic environment, one needs to define the word humanistic. The dictionaries offer us the different meanings of humanistic. According to Cambridge Dictionary, humanistic is an adjective verb and as an adjective verb, it means " treating people with respect and making certain they are safe, happy, healthy, etc". The definition focuses on the concern for proper treatment of people and their physical and psychological well-being. In the context of organizational management, it means that the management has a strong interest in human welfare, values, and dignity (McLeod. 22020) and not on rules, procedures, and obedience to authority to achieve the organizational objective as the bureaucratic management does (Friedrich, 1940, Finer, 1941 as cited by Abun, et.al. 2021). Adaui \& Habisch, (2013) contended that the concern of the management is human dignity which is defined as how the management treats their employees with respect and finds ways how to make them happy in the workplace. This is in line with the concern of humanistic psychology. Humanistic psychology emphasizes an approach that is centred on the whole human being (Cherry, 2020). As advised by humanistic psychology, the focus of management is to allow people to exercise their free will, develop their self-efficacy and actualize their full potentials. Mele (2016) argued that humanistic management seeks profits for human ends. In other words, the focus of management is the employees and not profit. Profit is only a means for human ends and 
therefore humans should not be treated as a means to an end which is profit. This concept emphasizes respect for human dignity and showing care for their well-being (Mele, 2016).

A humanistic environment is the opposite of a mechanistic environment. The humanistic environment is a result of humanistic management practices which focus on the well-being of human beings or employees (Abun, et.al, 2021). While the mechanistic environment is the result of mechanistic management which focuses on techniques or procedures (Mele, 2016). In this environment, the employees are required to follow the prescribed procedures and techniques to perform their job to achieve their goals. In this regard, the concern of the management is providing procedures and techniques to be followed by employees in carrying out their tasks. The employees are not free to initiate their ways to perform their tasks but only to follow the prescribed techniques or procedures. This management has been criticized as treating people like machines (Abun, et.al, 2021) and therefore it is dehumanizing (Bodley, 2002). Though procedures and techniques cannot be separated from doing a job, however, the focus of humanistic management is the well-being of a human person which includes physical and psychological well-being. Caring for the employees is the central concern of humanistic management. Based on these concepts, we can define what a humanistic environment is. Abun, et.al (2021) defined a humanistic work environment as a "work condition" in which employees are treated as human beings with dignity. Human being has dignity because of reason or rationality and consequently, a human being has free will. Therefore, recognizing human dignity means that the management treats the employees as rational beings and allows the employees to exercise free will in carrying out their duties and responsibility. In this regard, the management must allow the employees to be autonomous and free in performing their tasks (Abun, et.al, 2021). Consequently, the management allows participation in decision-making. Peter Drucker argued that management is about people which suggests that management needs to respect the whole person with his values, power, structure, and responsibilities(Linkletter and Maciariello 2011; Maciariello 2014). Lilienthal (1967as cited by Mele, 2016) contended that management should understand the individuals and motivate them to attain their goals. This idea suggests that management is not only acting as a supervisor but motivators and facilitators. Bersin (2014 as cited by Abun, 2021) identified the elements of a humanistic environment such as meaningful work, great leadership, growth opportunities, inclusiveness, flexibility, a fun environment and trusted leadership. Abun, et.al. (2021) argued that meaningful work can only be achieved when the employees are given the autonomy and freedom to exercise their duties and responsibilities toward the attainment of the goals. He argued further that a great and trusted leader helps the employees to grow. Thus, a humanistic environment is marked by inclusivity which means no discriminatory treatment and a fun environment.

Though certain authors pointed out that humanistic management does not work and does not support organizational success as pointed out by McGuire, et.al (2005), however, there are also some studies proving otherwise which found favourable findings concerning the effect of humanistic environment or humanistic management on organizational success or performance. For example, Daley (1986) found a moderate correlation between humanistic management and organizational performance. Abun, et.al (2021) also found a positive correlation between humanistic management practices to the work engagement of employees. A certain study also found a positive influence of humanistic management practices and corporate social responsibility (Hu, et.al, 2018).

\section{Entrepreneurial environment}

To understand the concept of entrepreneurial environment, we need to understand the meaning of environment and the word "entrepreneurial". According to Merriam-Webster Dictionary, environment means "the circumstances, objects, or conditions by which one is surrounded" or "the aggregate of social and cultural conditions that influence the life of an individual or community". Cambridge Dictionary defines it as "the conditions that you live or work in and the way that they influence how you feel or how effectively you can work". In the summary, the environment is a condition that surrounds someone that can affect one's work, mind, and behaviour. Thus, this definition provides a multidimensional construct of the work environment which includes a physical, social, cultural, and psychological dimension of the environment. While the word "entrepreneurial" is the adjective verb of the entrepreneur which is defined as "the one who organizes, manages, and assumes the risks of a business or enterprise" or "a person who starts a business and is willing to risk a loss to make money" (Online Merriam Webster Dictionary). The key element of this definition is risk-taking. A similar definition is found in the Dictionary.Com which defines an entrepreneur as "a person who organizes and manages any enterprise, especially a business, usually with considerable initiative and risk". Schumpeter (1934) defined an entrepreneur as "the bearers of uncertainty and who are not afraid of taking the risk". There is another additional element found in the definition of entrepreneur from Dictionary. Com and Schumpeter (1934) namely initiation and bearer of uncertainty. Based on those definitions, the characteristics of an entrepreneur are risk-taker, initiator, and uncertainty bearer. Thus, the word "entrepreneurial" has something to do with certain characteristics of an entrepreneur. Ki-Wong et.al (2005) identified two strong characteristics of an entrepreneur such as risk-taking propensity and need for achievement. While Gurol and Atsan (2006) mentioned six entrepreneurial characteristics and they are tolerance for ambiguity, self-confidence, risk-taking propensity, internal locus of control (Rotter, 1966), higher need for achievement (McClelland, 1961), and higher innovativeness.

After knowing those definitions of environment, entrepreneurial, and entrepreneur, one can define what entrepreneurial environment is. It is referring to a workplace where autonomy, freedom, risk-taking, creativity, and innovation are allowed or encouraged (Abun, et.al, 2021). Within this environment, employees are rewarded when they propose innovation to solve an existing problem and allowed to introduce a new method of doing a thing (Langer, et.al. 2019), Employees are encouraged to bring out new ideas on how to solve the existing problem, to compete for one another, motivated to go higher, motivated to take a risk, and allowing freedom to perform works in their way to achieve result because result matters and not process (Abun, 2021). 
Related to the effect of the entrepreneurial environment on the business performance, studies had been done by Musthofa, et.al (2017), Radipere (2014), Cuevas-Vargas, et.al (2019), Suryna, et.al (2019), Yi, et.al (2021), Mahmood and Hanafi (2013), and Akbar, et.al (2020), Fairos, et.al (2010), Kraus, et.al (2011), Zulkifli and Rosli (2013), and Oyeku, et.al (2020). These studies indicate entrepreneurial work environment matters to the business or organizational performance. Organizational success and competitiveness require an entrepreneurial environment in which the employees release their potentials to achieve organizational success. All their studies found that entrepreneurial orientation work environment is the strongest predictor of business performance. They even recommended that an entrepreneurial orientation work environment is necessary at the beginning stage of a business.

\section{Work Self-Efficacy and Its Sources}

Recently self-efficacy has increasingly become an important research topic because of its relevance to work performance which led Schwarzer, \& Jerusalem, (1995) to construct a general self-efficacy scale. The scale has been used and modified by some to measure work-related self-efficacy. Originally the self-efficacy theory was introduced by Bandura (1977) when he argued that performance is influenced by the individual's perception of his/her capability. Bandura (1977) believed that all individuals are capable to achieve their goals provided that they have the opportunity and the self-efficacy to pursue their goals. It is argued further that those who are successful are not necessarily better than those who are still struggling because they might not have the opportunities to obtain mastery experience which is necessary to develop self-efficacy (Gallagher, 2012). Self-efficacy is defined as one's belief in his/her capability to reach a certain level of performance (Bandura, 1994). It is an optimistic self-belief in one's capability to perform certain tasks and accomplish the goal. Such self-belief influences how someone feels thinks, and motivates himself/herself how to behave. It supports the accomplishment of tasks and objectives. When one has a strong self-efficacy belief, he/she can take the difficult tasks and see difficult tasks as challenges (Bandura, 1994). He/she tends to set challenging goals to achieve and he/she would find means or ways to achieve them and never give up on problems or challenges and always look at problems and challenges as a lesson to learn and improve.

Self-efficacy belief is not innate because many factors affect self-efficacy belief which has nothing to do with traits or character. Bandura (1977) had identified four sources of self - efficacy namely enactive mastery experience, vicarious experience, verbal persuasion, and physiological and affective states. Enactive mastery experience refers to the successful experience in the past in performing a certain task. The person's experience affects his/her elf-efficacy belief that he/she can do it again. We often hear people say, "If I did it successfully before, I can do it too now". The successful experience motivates the person to take the challenge and pursue the task. Besides one's own experience, one's self-efficacy belief can be the result of watching someone's experience in performing a certain task which is called vicarious experience. He/she has witnessed his/her peers doing it successfully and now he/she compares himself/herself with them and he/she believes that he/she can do it too. We often also hear people say, "If they can do it, why can't I?" Other people's experience becomes the source of motivation for a person to motivate himself/herself that he/she also do what others are doing. From observing others' experiences, one can get a new idea of how to execute the new task (Hoffart, 2017). Beyond experience, one gains self-efficacy belief after hearing people's positive comments which are called verbal persuasion. Recognition and encouragement from other people or one's idol, help someone to believe in himself/herself that he/she is capable. Verbal persuasion from others helps boost one's self-confidence to carry out a difficult task. However, even if someone has many experiences and supports from other people, those are not enough if the physical and emotional state of the person does not allow the person to perform an activity. The physical and emotional state may affect the self-efficacy of the person to do a task. For example, when one experiences injury, or experiences depression, one may be discouraged to do an activity. It is important to have physical and emotional fitness. Though physical and emotional well-being is not a strong determinant factor to predict self-efficacy, however, Bandura (1982) argued that boosting self-efficacy is much easier when one is feeling healthy and well. Thus, someone needs to manage anxiety and enhance mood when confronted by challenging situations (Lopez-Garrido, 2020).

The author of self-efficacy theory is Bandura (1977) and he defined self-efficacy as the person's belief in his/her capability to perform successfully certain behaviour or activity. Such belief is influenced by perceived individual capabilities and other individual factors and environmental factors. Studies have found that self-efficacy is context-dependence which means that the context or the environment where the behaviour is performed may serve as a barrier or facilitator. The work environment may promote or demote self-efficacy. The organizational theorist argues that the environment or the context where people are working can influence selfefficacy (Block, 1987, Conger, 1986). For example, empowering leadership and empowered managers would help to enhance selfefficacy. Nordlof, et.al (2019) argued out that self-efficacy is context - dependence because the social environment can limit or boost self-efficacy. Conger and Kanungo (1988) identified several contextual elements that influence self-efficacy such as organizational factors, supervisory style of leadership, and reward system. Conger and Kanungo recommended that enhancing employees' selfefficacy is necessary to eliminate work environment factors that are not promoting self-efficacy to grow. 


\section{Conceptual Framework}

Independent Variables

\section{Attitude toward work:}

Cognitive Attitude \& Affective Attitude

\section{Work Environment:}

Humanistic environment \& Entrepreneurial environment
Dependent Variable

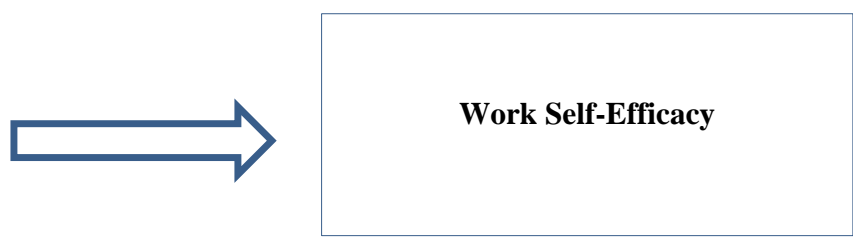

Figure 1: The conceptual framework indicates the correlation between the independent variables and dependent variables. Attitude toward work and work environment are predictors of self-efficacy; Source: Abun, et.al (2021), Pepe, et.al (2010).

\section{Statement of the problems}

As indicated by the conceptual framework the study aims to determine the influence of attitude toward work and work environment on work self-efficacy. It specifically seeks to answer the following research problems:

i. What is the attitude of employees toward their work in terms of:

a. Cognitive attitude

b. Affective attitude

ii. What is the work environment of the Divine Word Colleges of Laoag in terms of:

a. Humanistic environment

b. Entrepreneurial environment

iii. What is the work self-efficacy of the employees?

a. Is there a relationship between attitude toward work, work environment, and self-efficacy?

\section{Assumption}

Attitude toward work and work environment affects self-efficacy, and they can be measured.

\section{Hypothesis}

Perception of people toward their work and the work environment may affect their work self-efficacy. Thus, the study hypothesizes that there is a correlation between attitude toward work, work environment, and self-efficacy.

\section{The Scope and Delimitation of the study}

The scope of the current study is the employees of the Divine Word College of Laoag, Ilocos Norte and it investigates only the attitude toward work specifically on the cognitive and affective dimension, work environment which include humanistic and entrepreneurial environment and work self-efficacy.

\section{Research Methodology}

As a general standard for scientific research, it has to follow the research methodology. The current research is following a specific method of investigation or research methodology. Wilkinson (2000) and Leedy (1974) opined that research methodology is an established process for conducting the inquiry. It applies certain methods to determine, select, and analyze the data related to the concerned topic. Therefore, current study utilizes methods of investigation such as research design, data gathering instruments method, the population of the study, the locale of the study, data gathering procedures, and the statistical treatment of data.

\section{Research Design of the study}

The research design of the study is the descriptive assessment and descriptive correlational research design. Ariola (2006) argued that a descriptive correlation study is to determine the relationship among variables without seeking to establish a causal connection. Descriptive research is simply describing a population, a situation, or a phenomenon. It describes profiles, frequency distribution, characteristics of people and, situations or phenomena. In short, it answers the question of what, when, how, where, and not why question (McCombes, 2020).

\section{The locale of the study}

The locale of the study was the Divine Word College of Laoag. This college is in Laoag City, the capital of Ilocos Norte. 


\section{Population}

The respondents of the study were the employees of the college. Considering the number of employees is limited, therefore, the total enumeration sampling used and all faculty and employees from the two colleges were taken as respondents.

\section{Data Gathering instruments}

The study adopted validated questionnaires of Abun, et.al (2021) on attitude toward work, and Abun, et. al (2021) on the work environment, and Pepe, et.al (2010) on Work Self-Efficacy.

\section{Data Gathering Procedures}

To preserve the integrity of scientific study the questionnaires were distributed only after the President of the college approved. The researcher sent a letter to the president and after the letter of the request was approved, the questionnaires were distributed by the researcher's representative. Then the researcher's representative from the college collected the data and submitted it to the researcher for tabulation.

\section{Ethical Procedures}

This research was conducted after the research ethics committee examined and approved the content if it does not violate ethical standards and if it does not cause harm to human life and the environment.

\section{Statistical Treatment of Data}

To analyze the data, descriptive and inferential statistics were used. The weighted mean was applied to determine the level of attitude of employees toward work, work environment and work self-efficacy. Multiple Linear Regression (MLR) was applied to measure the correlation between the attitude of employees toward work, work environment, and work self-efficacy. The following ranges of values with their descriptive interpretation used:

$\begin{array}{ll}\text { Statistical Range } & \text { Descriptive Interpretation } \\ 4.21-5.00 & \text { strongly agree/Very High } \\ 3.41-4.20 & \text { Agree/High } \\ 2.61-3.40 & \text { somewhat agree/ Moderate } \\ 1.81-2.60 & \text { Disagree/Low } \\ 1.00-1.80 & \text { Strongly disagree/Very Low }\end{array}$

\section{Data Presentation and Analysis}

As scientific research requires, the study must follow prescribed research methodology and be supported by data. Thus, this part presents the data that was gathered through research questionnaires. The presentation and analysis follow the arrangement of the statement of the problems.

\section{Problem no 1: What is the attitude of employees toward their work in terms of:}

a. Cognitive attitude

b. Affective attitude

Table 1: The Attitude of Employees toward their work in terms of Cognitive Attitude

\begin{tabular}{lcc}
\hline Indicators & Mean & DR \\
\hline 1. I think I know my work. & 4.00 & $\mathrm{~A}$ \\
\hline 2. I think that I have the knowledge to perform my work. & 3.97 & $\mathrm{~A}$ \\
\hline 3. I think that I have enough experience to carry out my tasks. & 3.92 & $\mathrm{~A}$ \\
\hline 4. I think that I am familiar with all the details of my work. & 3.92 & $\mathrm{~A}$ \\
\hline 5. I think that I have the skills to carry out my work. & 3.95 & $\mathrm{~A}$ \\
\hline 6. I think I can carry out my work without the help of others. & 3.78 & $\mathrm{~A}$ \\
\hline Composite Mean & 3.92 & $\mathrm{~A}$ \\
\hline
\end{tabular}

Source: Abun, et.al (2021).

Based on the data presented in the table, it shows that as a whole the cognitive attitude of employees toward their work gains a composite mean rating of 3.92 which is described as "agree/high". This rating indicates that the cognitive attitude of employees toward their work is not very high and it is also not very low, low, or moderate but it is high. Even when the indicators are taken separately, they all are rated within the same composite mean rating with the same description as "high". This finding suggests that employees think that they know their work (4.00), know to perform their work (3.97), have enough experience to carry out their task (3.92), are familiar with the details of their work (3.92), have skills to carry out their work (3.95) and can carry out their work without the help of others (3.78). 
Table 2: The Attitude of Employees toward their work in terms of Affective Attitude

\begin{tabular}{lccc}
\hline Indicators & Mean & DR \\
\hline 1. I feel happy with my work. & 3.74 & $\mathrm{~A}$ \\
\hline 2. I love the work I am doing. & 3.86 & $\mathrm{~A}$ \\
\hline 3. My work gives me satisfaction. & 3.87 & $\mathrm{~A}$ \\
\hline 4. I feel good because my work matches my skills. & 3.85 & $\mathrm{~A}$ & \\
\hline 5. My work is important to me. & 3.93 & $\mathrm{~A}$ & \\
\hline 6. My work gives me a sense of meaning. & 3.91 & $\mathrm{~A}$ \\
\hline Composite Mean & 3.86 & $\mathrm{~A}$ & \\
\hline
\end{tabular}

Source: Abun, et.al (2021).

Following the cognitive attitude toward work is the affective attitude toward work. As reflected by the data in the table, it reveals that as a whole, the affective attitude of employees toward their work obtained a composite mean of 3.86 which is interpreted as "agree/high". This mean rating signifies that as a whole the employees' affective attitude toward their work is not very high and it is also not very low, low, or moderate but it is high. Even if the items are taken singly, all items are rated within the same mean rating with the interpretation of "high/agree". This suggests that all employees agree that they are happy with their work (3.74), love their work (3.86), their work gives them satisfaction (3.87), sense of meaning (3.91), they feel good because it matches their skills and thinks that their work is important to them.

Table 3: Summary of Attitude of Employees toward their Work

\begin{tabular}{lrc}
\hline Items & Mean & DR \\
\hline 1. Cognitive Attitude & 3.92 & $\mathrm{~A}$ \\
\hline 2. Affective Attitude & 3.86 & $\mathrm{~A}$ \\
\hline Weighted Mean & $\mathbf{3 . 8 9}$ & $\mathbf{A}$
\end{tabular}

In summary of the attitude of employees toward their work, the data manifest that as a whole the attitude of employees toward their work is considered high. This rating suggests that the employees believe that they know their work and love their work.

Problem 2: What is the work environment of the Divine Word Colleges in the Ilocos Region in terms of:

a. Humanistic environment

b. Entrepreneurial environment

Table 4: The Work Environment of the Divine Word Colleges in the Ilocos Region in terms of Humanistic Environment

\begin{tabular}{lcc}
\hline Indicators & Mean & Dr \\
\hline 1. The management considers the ideas of employees when making decisions. & 3.17 & SWA \\
\hline 2. The management always tries its best to serve the needs of employees. & 3.15 & SWA \\
\hline 3. The management listens to the employees when the employees counter problems in their work. & 3.16 & SWA \\
\hline 4. The management respects and treat the employees as human beings with dignity. & 3.23 & SWA \\
\hline 5. The management recognizes the effort of the employees to help the institution. & 3.21 & SWA \\
\hline 6. There is open communication between employees and management. & 3.10 & SWA \\
\hline 7. When making decisions, the management always considers the consequence of the decision on the & 3.17 & SWA \\
employees. & 3.12 & SWA \\
\hline 8. The management prioritizes the employees' condition first before work. & 3.16 & SWA \\
\hline Composite Mean & & S
\end{tabular}

Source: Abun, et.al (2021).

As indicated by the data on the table, it displays that as a whole, the humanistic work environment of the Divine Word College of Laoag gained a composite mean rating of 3.16 which is described as "somewhat agree/moderate". This indicates that as a whole the humanistic environment is not very high or high and it is also not very low or low but to a moderate extent. In other words, the environment is not very humanistic but moderately humanistic. Even if the indicators are taken separately, all indicators are rated within the same mean rating level with the same interpretation of "somewhat agree/moderate". In other words, all employees think that management's concern for the employees is only to a moderate extent, and it is not very high and not very low. This is evidenced by the individual rating that the management moderately considers the ideas of employees when making decisions (3.17), prioritizes the employees' condition first before work (3.12), tries its best to serve the needs of employees. tries its best to serve the needs of employees (3.15), listens to the employees when the employees counter problems in their work (3.16), respects and treat the employees as human beings with dignity (3.23), recognizes the effort of the employees to help the institution (3.21), considers the consequence of the decision on the employees (3.17), and prioritizes the employees' condition first before work (3.12). 
Table 5: The Work Environment of the Divine Word Colleges in the Ilocos Region in terms of Entrepreneurial Environment

\begin{tabular}{lcc}
\hline Indicators & Mean & Dr \\
\hline 1. Employees are encouraged to take the risk. & 3.26 & SWA \\
\hline 2. Employees in this organization are praised for developing innovative solutions. & 3.21 & SWA \\
\hline 3. This organization has a strong commitment to innovation. & 3.24 & SWA \\
\hline 4. People who develop innovative solutions to problems are recognized. & 3.17 & SWA \\
\hline 5. This institution is a very dynamic and entrepreneurial place. People are willing to stick their necks out & 3.19 & SWA \\
and take risks. & & \\
\hline 6. Employees are free to perform their work in their way to achieve the result. & 3.25 & SWA \\
\hline 7. The institution is result-oriented and not process-oriented. & 3.21 & SWA \\
\hline Composite Mean & 3.22 & SWA \\
\hline Source: Abun, et.al (2021) & &
\end{tabular}

Source: Abun, et.al (2021)

After the humanistic work environment is the entrepreneurial work environment. As manifested by the data on the table, it appears that as a whole the entrepreneurial work environment of the Divine Word College of Laoag got a 3.22 composite mean rating which is understood as "somewhat agree/moderate". This rating demonstrates that as a whole the entrepreneurial work environment is not very high or high and it is also not very low, or low but it is moderate. Even when the indicators are taken separately, all items got the same level of mean rating within the same interpretation which is somewhat "somewhat agree or moderate". Employees believe that the management moderately encourages employees to take a risk (3.26), praises employees for developing innovative solutions (3.21), recognizes employees who propose innovative solutions to existing problems (3.17), and also the employees believe that the institution has a moderate commitment to innovation (3.24), has a moderate commitment to result-oriented behaviour (3.21) and moderately allows the employees to perform their work in their way to achieve the result (3.25).

Table 6: Summary of Work Environment

\begin{tabular}{lcc}
\hline Items & Mean & DR \\
\hline 1. Humanistic Environment & 3.16 & SWA \\
\hline 2. Entrepreneurial Environment & 3.22 & SWA \\
\hline Weighted Mean & 3.19 & SWA \\
\hline
\end{tabular}

In summary, the data shows that the work environment of the institution is not very humanistic and not very entrepreneurial but moderately humanistic and moderately entrepreneurial. It just means that the management is not strongly but moderately pro employees and the management is not very strong in supporting entrepreneurial behaviour by allowing employees to be innovative and creative.

Problem 3: What is the work self-efficacy of the employees?

Table 7: The Work Self-Efficacy of Employees

\begin{tabular}{lcc}
\hline Indicators & Mean & DR \\
\hline 1. I can achieve the goals assigned to me. & 3.88 & $\mathrm{~A}$ \\
\hline 2. I can follow the schedules and working deadlines. & 3.92 & $\mathrm{~A}$ \\
\hline 3. I can learn new working methods. & 3.91 & $\mathrm{~A}$ \\
\hline 4. I believe I can concentrate all my energy on work. & 3.89 & $\mathrm{~A}$ \\
\hline 5. I know that I can finish assigned work. & 3.91 & $\mathrm{~A}$ \\
\hline 6. I can collaborate with other colleagues. & 3.88 & $\mathrm{~A}$ \\
\hline 7. I can work with people of diverse experiences and ages. & 3.86 & $\mathrm{~A}$ \\
\hline 8. I can establish good relationships with direct superiors. & 3.89 & $\mathrm{~A}$ \\
\hline 9. I can behave respectfully with clients. & 3.95 & $\mathrm{~A}$ \\
\hline 10. I can work in a team. & 3.94 & $\mathrm{~A}$ \\
\hline Composite Mean & $\mathbf{3 . 9 0}$ & $\mathrm{A}$ \\
\hline So
\end{tabular}

Source: Pepe, et.al (2010)

Based on the data presented in the table, it shows that as a whole the work self-efficacy of employees gained a composite mean rating of 3.90 which is considered as "agree/high". This composite mean rating points out that as a whole the work self-efficacy of employees is not very high and it is also not very low or low but it is high. Even when the indicators are taken separately, they all are rated within the same mean rating and the same interpretation which is agree/high. Such rating suggests that the employees agree that they can achieve the goals assigned to them (3.88), can follow the schedules and working deadlines (3.92), can learn new working methods (3.91), can concentrate all the energy on work (3.89), can finish assigned work (3.91), can collaborate with other colleagues (3.88), can work with people of diverse experiences and ages (3.86), can establish good relationships with direct superiors (3.89), can behave respectfully with clients (3.95), and can work in a team (3.94). 
Problem 4: Is there a relationship between Attitude toward Work, Work Environment, and Self-efficacy

Table 8: Relationship between attitude toward work, work environment, and Self-efficacy

\begin{tabular}{lllll}
\hline \multicolumn{2}{l}{ Model Summary } & & \\
\hline Model & R & R Square & Adjusted R Square & Std. Error of the Estimate \\
\hline $\mathbf{1}$ & $.733^{\text {a }}$ & .538 & .533 & .45928 \\
\hline \multicolumn{2}{l}{ a. Predictors: (Constant), work environment, attitude toward work } & \\
\hline
\end{tabular}

Table 9: ANOVA and Coefficients

\begin{tabular}{|c|c|c|c|c|c|c|c|c|c|}
\hline \multicolumn{10}{|c|}{ ANOVA $^{a}$} \\
\hline \multicolumn{2}{|l|}{ Model } & \multicolumn{2}{|c|}{ Sum of Squares } & $\mathrm{df}$ & \multicolumn{2}{|c|}{ Mean Square } & $\mathrm{F}$ & \multicolumn{2}{|c|}{ Sig. } \\
\hline \multirow[t]{3}{*}{1} & Regression & & & 2 & \multicolumn{2}{|c|}{22.932} & 108.717 & \multicolumn{2}{|c|}{$.000^{\mathrm{b}}$} \\
\hline & Residual & & & 187 & \multicolumn{2}{|c|}{.211} & & & \\
\hline & Total & & & 189 & & & & & \\
\hline \multicolumn{10}{|c|}{ a. Dependent Variable: Work Self-Efficacy b. Predictors: (Constant), work environment, attitude toward work } \\
\hline \multicolumn{10}{|c|}{ Coefficients $^{\mathrm{a}}$} \\
\hline \multirow[t]{2}{*}{ Model } & & & \multicolumn{3}{|c|}{ Unstandardized Coefficients } & $\begin{array}{l}\text { Stan } \\
\text { Coef }\end{array}$ & $\begin{array}{l}\text { ized } \\
\text { ents }\end{array}$ & \multirow[t]{2}{*}{$\mathrm{t}$} & \multirow[t]{2}{*}{ Sig. } \\
\hline & & & $\mathrm{B}$ & & Std. Error & Beta & & & \\
\hline \multirow[t]{3}{*}{1} & (Constant) & & .940 & & .204 & & & 4.614 & .000 \\
\hline & Attitude tow & ork & .715 & & .061 & .688 & & 11.651 & .000 \\
\hline & Work Envir & & .059 & & .044 & .078 & & 1.328 & .186 \\
\hline
\end{tabular}

a. Dependent Variable: Work Self-efficacy

Source: IBM SPSS Software

As reflected in the correlation table, the Multilinear regression analysis indicated that as a whole, the employees' work attitude and work environment considered together significantly predicted the work self-efficacy of the respondents, $\mathrm{F}(2,187)=108.72 p<.01$ with $73 \%$ overlap between the two predictors and the outcome of work self-efficacy. This finding suggests that both, attitude toward work and work environment could affect work self-efficacy. However, taking it singly, the data reveals that work environment is not correlated with the work self-efficacy and it is only the respondents' attitude towards work has a significant relationship with work self-efficacy, with a slope of .715 ( $p=.000) ; .940$ quantified the Y-intercept for the regression equation.

\section{Result and Discussion}

Following the result of the study, it shows that the attitude of employees toward their work is considered high which indicates that they believe that they know their work and love their work. However, given such a high cognitive and affective attitude, the work environment does not follow. The humanistic and entrepreneurial work environments are rated moderately. The management is not so much employees-oriented and innovation and creativity-driven. The finding of correlation analysis indicates that though the work environment is not very high or high but moderate, however, it does not affect the self-efficacy of employees but only the attitude toward work. Taking the attitude toward work and the work environment together, both affect the work self-efficacy of employees.

The finding of the study recommends that developing work self-efficacy of employees is necessarily paying attention to their attitude toward work and work environment. Enhancing the employees' attitude toward work can help boost employees' work self-efficacy and at the same time improving the work environment can help the development of work self-efficacy. Failing to pay attention to the attitude of employees and work environment may affect work self-efficacy negatively. Thus, the management's function is to identify areas that affect the attitude of employees toward their work and improve the humanistic and entrepreneurial environment of the organization.

The current finding contributes to the enrichment of the discussion on work self-efficacy and factors that affect work self-efficacy. Work self-efficacy is not just influenced by other factors such as work experience, and education (Abun, 2021) or mastery experience, vicarious experience, verbal persuasion, and physical/emotional condition (Bandura, 1977) but also attitude and work environment. Even if the employees have self-efficacy but if they have a negative attitude and a bad environment, then work self-efficacy can be affected. 


\section{Conclusion}

The study aims to determine the effect of attitude toward work and work environment on the work self-efficacy of the employees. The study found that the cognitive and affective attitude of employees toward their work is high but the work environment particularly humanistic and entrepreneurial work environment is moderate. It is also found that the work self-efficacy of the employees is considered high. The study further found that both attitudes toward work and work environment when they are taken together correlate to work self-efficacy. It means that both can affect the work self-efficacy of employees. Based on this finding, then the hypothesis of the study is accepted.

\section{References}

Abun, D., Ubasa, A.L.A., Magallanes, T., Encarnacion, M.J. \& Ranay, F.B. (2021). Attitude toward the work and its influence on the Individual work performance of employees: Basis for Attitude Management. Technium Social Science Journal, 18, 378-394.

Abun, D., Magallanes, T., Acidera, E.B. Encarnacion, M.J., \& Domingcil, C.U. (2021). Work Environment and work Engagement of Employees of the Catholic Colleges in the Ilocos Region, Philippines. Technium Social Science Journal, 19, 439-464.

Abdalkrim, G.M. \& Elhalim, T.A.A. (2016). Attitude toward Work, Job Satisfaction, and Job Performance. International Journal of Academic Research in Business and Social Sciences, 6(12).

Ajzen, I. (1993). New Directions in Attitude Measurement. New York: Walter de Gruyter.

Akbar, F., Bon, A.T.B., Wadood, F., \& Alsubari, N.S.A. (2020). Entrepreneurial orientation and firm performance: The mediation effect of open innovation in the Malaysian furniture industry. Proceedings of the 5th N.A International Conference on Industrial Engineering and Operations Management Detroit, Michigan, USA. Retrieved from http://www.ieomsociety.org/detroit2020/papers/522.pdf

Akcay, R., Ulutas, M. \& Sevinc, N. (2016). Attitudes towards work in Educational Institutions. Journal of Human Sciences 13(1): 1072 .

Almeida, A., Faisca, L. \& de Jesus, S.N. (2012). Positive attitudes at work, some of its consequents and antecedents: a study with hotel professional. International Journal of Economics and Management Sciences, 1(6), 71-82.

Al-Omari, K. \& Okasheh, H. (2017). The Influence of Work Environment on Job Performance: A Case Study of Engineering Company in Jordan. International Journal of Applied Engineering Research, 12(24), 15544-15550.

Allport, G. W. (1935). Attitudes, a Handbook of Social Psychology (Murchison, C., Ed.). Massachusetts: Clark University Press.

Aries, S., Rizqi, M. (2013). Employee's Job Performance: The Effect of Attitude toward Works, Organizational Commitment, and Job Satisfaction. Jurnal Teknik Industri, Vol. 15, No. 1, 13-24

Ariola, M.M. (2006). Principles and Methods of Research. Manila: Rex Book Store

Bandura, A. (1977). Self-efficacy: Toward a unifying theory of behavioural change. Psychological Review, 84(2), 191-215.

Bandura, A. (1994). Self-efficacy. In V. S. Ramachandran (Ed.), Encyclopedia of human behaviour, 4, 71-81. New York: Academic Press. (Reprinted in H. Friedman [Ed.], Encyclopedia of mental health. San Diego: Academic Press, 1998).

Baysal, A.C. \& Tekarslan, E. (1996). Isletmeciler Için Davranıs Bilimleri. Istanbul: Avcıol.

Bersin, J. (2014). The Five Elements of a Simply Irresistible Organization. Forbes. Retrieved from https://www.forbes.com

Block, P. (1987) The empowered manager. San Francisco: Jossey-Bass.

Borst, R. T., Kruyen, P. M., Lako, C. J., \& de Vries, M. S. (2020). The Attitudinal, Behavioral, and Performance Outcomes of Work Engagement: A Comparative Meta-Analysis Across the Public, Semipublic, and Private Sector. Review of Public Personnel Administration, 40(4), 613-640. https://doi.org/10.1177/0734371X19840399

Briner, R. B. (2000) Relationships between work environments, psychological environments and psychological well-being: an indepth review. Occup. Med. 50 (5), 299-303. Retrieved from http://occmed.oxfordjournals.org/content/50/5/299.full.pdf

Cherry, K. (2021). Attitudes and Behavior in Psychology. Very Well Mind. Retrieved from https://www.verywellmind.com/attitudeshow-they-form-change-shape-behavior-2795897

Cherry, K. (2020). Attitudes and Behavior in Psychology. Very Well Mind. Retrieved from https://www.verywellmind.com/attitudeshow-they-form-change-shape-behavior-2795897

Dewey, J. (1922). Human Nature and Conduct. New York: Henry Holt and Company

Conger, J. A. \& Kanungo, R.N. (1988). Empowerment Process: Integrating Theory and Practice. The Academy of Management Review, 13 (3), 471-482.

Conger, J. (1986). Empowering leadership. Working paper. Montreal: McGill University.

Cuevas-Vargas, H., Parga-Montoya, N., \& Fernández-Escobedo, R. (2019). Effects of Entrepreneurial Orientation on Business Performance: The Mediating Role of Customer Satisfaction-A Formative-Reflective Model Analysis. SAGE Open. https://doi.org/10.1177/2158244019859088

Daley, D. M. (1986). Humanistic Management and Organizational Success: The Effect of Job and Work Environment Characteristics on Organizational Effectiveness, Public Responsiveness, and Job Satisfaction. Public Personnel Management, 15(2), 131142. https://doi.org/10.1177/009102608601500204

Duru, C. E. \& Shimawua, D. (2017). The Effect of Work Environment on Employee Productivity: A Case Study of Edo City Transport Services Benin City, Edo State Nigeria. European Journal of Business and Innovation Research, 5(5), 23-39. 
Fairoz, F.M., Hirobumi, T. \& Tanaka, Y. (2010). Entrepreneurial Orientation and Business Performance of Small and Medium Scale Enterprises of Hambantota District Sri Lanka. Asian Social Science, 6(3).

Finer, H. (1941). Administrative responsibility in democratic government. Public Administration Review, Vol. 1: 335-350.

Freiling, J. \& Schelhowe, C.L. (2014). The impact of Entrepreneurial Orientation on the Performance of Internationalization. Journal of Entrepreneurship, Management, and Innovation, 10(4).

Friedrich, C. (1940). Public policy and the nature of administrative responsibility. In C. J. Friedrich (Ed.), Public Policy: 3-24. Cambridge: Harvard University Press.

Gallagher, M.W. (2012). Self-Efficacy. In Encyclopedia Human Behavior (Second Edition). ScienceDirect. Retrieved from https://www.sciencedirect.com/topics/psychology/self-efficacy-theory

Gurol, Y. \& Atsan, N. (2006). Entrepreneurial Characteristics amongst University Students: Some Insights for Entrepreneurship and Training in Turkey. Education +Training, 48(1), 25-38. https://doi.org/10.1108/00400910610645716.

Hafeez, I., Yingjun, Z., Hafeez, S. \& Cheema, K.R. (2019). Impact of workplace environment on employee performance: mediating role of employee health. Business Management and Education 17(2):173-193

Hettiararchchi, H.A.H. \& Jayarathna, S.M.D.Y (2014). The effect of Employee Work-Related Attitudes on Employee Job Performance: A Study of Tertiary and Vocational Education Sector in Sri Lanka. IOSR Journal of Business and Management (IOSR-JBM), 16(4), 74-83.

Hoffart, A. (2017). Guided Mastery Therapy. In Reference Module in Neuroscience and Biobehavioral Psychology. ScienceDirect. Retrieved from https://www.sciencedirect.com/topics/psychology/self-efficacy-theory

Hu, Y., Chen, S. \& Wang, J. (2018). Managerial Humanistic Attention and CSR: Do Firm Characteristics Matter? Sustainability, 10(11), 4029. https://doi.org/10.3390/su10114029.

Khan, I. \& Ghauri, T.H. (2014). Impact of Attitude on Employees Performance: A Study of Textile Industry in Punjab, Pakistan. World Applied Sciences Journal 30(25),191-197.

Ki-Wong, W., Cheung, H.M, \& Venuvinod, P.K. (2005). Individual Entrepreneurial Characteristics and Entrepreneurial Success Potential. International Journal of Innovation and Technology Management, 2(3), 277-292.

Koffka, K. (1935). Principles of Gestalt Psychology, New York: Harcourt, Brace, and Co.

Kraus, S., Rigtering, J.P.C., Hughes, M. \& Hosman, V. (2011). Entrepreneurial orientation and the business performance of SMEs: a quantitative study from the Netherlands. Review of Managerial Science, 6, 161-182.

Langer, J., Feeney, M.K. \& Lee, S.E. (2019). Employee Fit and Job satisfaction in Bureaucratic and Entrepreneurial Work Environment. Review of Public Personnel Administration 39(1) 135-155.

Lilienthal, D.E. 1967. Management: a Humanist Art. New York: Carnegie Institute of Technology.

Liska, A. E. (1974). The Impact of Attitude on Behavior: Attitude-Social Support Interaction. Pacific Sociological Review, 17(1), 83-97.

Leedy, P.D. (1974). Practical research: planning and design. New York: Macmillan

Linkletter, K.E., and J.A. Maciariello. 2011. Drucker's lost art of management: peter Drucker's timeless vision for building effective organizations. New York: McGraw-Hill.

Lopez-Garrido, G. (2020). Self-Efficacy Theory. Simply Psychology. Retrieved from https://www.simplypsychology.org/selfefficacy.html

Mahmood, R. \& Hanafi, N. (2013). Entrepreneurial Orientation and Business Performance of Women-Owned Small and Medium Enterprises in Malaysia: Competitive Advantage as a Mediator. International Journal of Business and Social Science, 4(1).

McGuire, D. Cross, C. \& O'Donnell, D. (2004). Why Humanistic Approaches in HRD Won't Work. Human Resource Development Quarterly, 16 (1), 131-137. Retrieved from SSRN: https://ssrn.com/abstract=818164

McLeod, S. (2020). Humanistic Approach. Simply Psychology. Retrieved from https://www.simplypsychology.org

Maciariello, J.A. (2014). A year with Peter Drucker: 52 weeks of coaching for leadership effectiveness. New York: Harper Collins.

McClelland, D. (1961). The Achieving Society. Princeton, N.J: Van Nostrand

McCombes, S. (2020). Descriptive Research. Scribbr. Retrieved from https://www.scribbr.com/methodology/descriptive-research/ Mele, D. (2016). Understanding Humanistic Management. Humanistic Management Journal, 1, 33-55.

Menon, A.S. \& Priyadarshini, R.G., (2018). A study on the Effect of workplace negativity factors on employee engagement mediated by emotional exhaustion. The 3rd International Conference on Materials and Manufacturing Engineering 2018. doi:10.1088/1757-899X/390/1/012027

Musthofa, W. S., Farida, N. \& Ngatno. (2017). Effect of Entrepreneurial Orientation on Business Performance. International Journal of Civil Engineering and Technology, 8(9), 82-90.

Myers, D. (2013). Social Psychology. New York: McGraw-Hills

Nordlof, C., Hallstrom, J. \& Host, G.E. (2019). Self-efficacy or context-dependency? Exploring teachers' perceptions of and attitudes towards technology education. International Journal of Technology and Design Education, 29, 123-141.

Oludeyi, O.S. (2015). A Review of Literature on Work Environment and Work Commitment: Implication for Future Research in Citadels of Learning. Journal of the Human Resources Management, 2(5).

Önal, S. E. (2015). Kamu Çalısanlarının Verimliliginde ice Yönelik Tutumlar, Örgütsel Adalet Algısı Ve Algılanan Sosyal Destegin Önemi, Kalkınmada Anahtar Verimlilik Dergisi, Say1:290, T.C.Bilim, sanayi ve Teknoloji Bakanlıg1.

Opperman C. S. (2002). Tropical Business Issues. London: Partner Price Water House Coopers (PWC). 
Ortmeyer, D. (1949). The Concept of Attitude. Proceedings of the Iowa Academy of Science, 56(1), 279-284. Available at: https://scholarworks.uni.edu/pias/vol56/iss1/39

Oyeku, O.M., Oduyoye, O., Elemo, G, N. (2020). The Effect of Entrepreneurial Orientation, Entrepreneurial Self-Efficacy, and Environmental Uncertainty on Entrepreneurial Success. International Journal of Small Business and Entrepreneurship Research, 8(4), 34-67.

Perloff R.M. (2013). The Dynamics of Persuasion: Communication and Attitudes in the 21 st century. New York: Routledge

Pepe, S.J., Farnese, M.L., Avalone, F. \& Vecchione, M. (2010). Work Self-Efficacy Scale and Search for Work Self-Efficacy Scale: A Validation Study in Spanish and Italian Cultural Contexts. Journal of Work and Organizational Psychology / Revista de Psicología del Trabajo y de las Organizaciones, 26(3), 201-210.

Radipere, S. (2014). The Effect of Entrepreneurial Orientation on Business Performance. Mediterranean Journal of Social Sciences 5(16).

Rotter, J. (1966). Generalized expectancies for internal versus external control reinforcements. Psychological Monographs, 80 (609).

Schwarzer, R., \& Jerusalem, M. (1995). A Generalized Self-Efficacy scale. In J. Weinman, S. Wright, \& M. Johnston, Measures in health psychology: A user's portfolio. Causal and control beliefs (pp. 35-37). Windsor, UK: NFER-NELSON.

Suryana, Ahman, E.\& Machmud, A. (2019). The Effect of Entrepreneurial Orientation on SMEs Business Performance in Indonesia. Journal of Entrepreneurship Education, 22(5).

Susanty, A. \& Miradipta, R. (2013). Employee's Job Performance: The Effect of Attitude toward Works, Organizational Commitment, and Job Satisfaction. Jurnal Teknik Industri 15(1)

Thurstone, L. L. (1929). The Measurement of Attitude. Chicago: University of Chicago Press.

Walden, R. (2004). Work Environment. In Encyclopedia Applied Psychology. ScienceDirect. Retrieved from https://www.sciencedirect.com/topics/social-sciences/work-environment

Wilkinson, D. (2000). The researcher's toolkit: the complete guide to practitioner research. New York: Routledge/Falmer

Yi, H.-T.; Amenuvor, F.E.; Boateng, H. (2021). The Impact of Entrepreneurial Orientation on New Product Creativity, Competitive Advantage and New Product Performance in SMEs: The Moderating Role of Corporate Life Cycle. Sustainability, 13, 3586. https://doi.org/10.3390/su13063586.

Yusuf, N. \& Metiboba S. (2012) Work environment and job attitude among employees in a Nigerian work organization. Journal of Sustainable Society, 1(2), 36-43.

Zulkifli, R.M. \& Rosli, M.M. (2013). Entrepreneurial Orientation and Business Success of Malay Entrepreneurs: Religiosity as Moderator. International Journal of Humanities and Social Science, 3(10).

Publisher's Note: SSBFNET stays neutral with regard to jurisdictional claims in published maps and institutional affiliations.

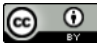

(C) 2021 by the authors. Licensee SSBFNET, Istanbul, Turkey. This article is an open access article distributed under the terms and conditions of the Creative Commons Attribution (CC BY) license (http://creativecommons.org/licenses/by/4.0/).

International Journal of Research in Business and Social Science (2147-4478) by SSBFNET is licensed under a Creative Commons Attribution 4.0 International License. 